\title{
Characterization of a New Arabidopsis Mutant Exhibiting Enhanced Disease Resistance
}

\author{
Herman Silva, Keiko Yoshioka, Hugo K. Dooner, and Daniel F. Klessig \\ Waksman Institute, Rutgers, The State University of New Jersey, 190 Frelinghuysen Rd., Piscataway, NJ \\ 08854-8020, U.S.A. \\ Accepted 9 August 1999.
}

In many plant-pathogen interactions, resistance is associated with the synthesis and accumulation of salicylic acid (SA) and pathogenesis-related (PR) proteins. At least two general classes of mutants with altered resistance to pathogen attack have been identified in Arabidopsis. One class exhibits increased susceptibility to pathogen infection; the other class exhibits enhanced resistance to pathogens. In an attempt to identify mutations in resistanceassociated loci, we screened a population of T-DNA tagged Arabidopsis thaliana ecotype Wassilewskija (Ws) for mutants showing constitutive expression of the $\underline{P R}-1$ gene (cep). A mutant was isolated and shown to constitutively express $P R-1, P R-2$, and $P R-5$ genes. This constitutive phenotype segregated as a single recessive trait in the Ws genetic background. The mutant also had elevated levels of SA, which are responsible for the cep phenotype. The cep mutant spontaneously formed hypersensitive response (HR)-like lesions on the leaves and cotyledons and also exhibited enhanced resistance to virulent bacterial and fungal pathogens. Genetic analyses of segregating progeny from outcrosses to other ecotypes unexpectedly revealed that alterations in more than one gene condition the constitutive expression of $P R$ genes in the original mutant. One of the mutations, designated cpr20, maps to the lower arm of chromosome 4 and is required for the cep phenotype. Another mutation, which has been termed cpr21, maps to chromosome 1 and is often, but not always, associated with this phenotype. The recessive nature of the cep trait suggests that the CPR20 and CPR21 proteins may act as negative regulators in the disease resistance signal transduction pathway.

Additional keywords: nahG, pathogen resistance, systemic acquired resistance.

When a plant is infected by a pathogen, one of several possible outcomes can occur. The plant may be unable to control the growth and/or spread of the pathogen, which leads to disease. Alternatively, the plant may be able to resist pathogen invasion. In some cases, resistance is passive; the plant fails to provide the appropriate environment to support pathogen

Corresponding author: Daniel F. Klessig; Telephone: 1-732-445-3805; Fax: 1-732-445-5735; E-mail: klessig @ mbcl.rutgers.edu

Current address of Herman Silva: Department of Biology, Faculty of Sciences, University of Chile, Casilla 653, Santiago, Chile. colonization. In other cases, resistance is an active process in which the plant induces a cascade of defense responses. Genetic studies of plant-microbe interactions have shown that active resistance is usually conditioned by a plant resistance gene, whose product directly or indirectly recognizes a racespecific avirulence determinant produced by the pathogen (Keen 1990; Scofield et al. 1996; Tang et al. 1996; Yang et al. 1997). One of the most visible signs that a plant is resisting pathogen attack is the development of a hypersensitive response (HR) on the inoculated tissue. The HR is characterized by small, necrotic lesions that form around the infection site (Matthews 1991) and may help restrict the growth and spread of the pathogen (Slusarenko et al. 1991). In addition, antimicrobial compounds (phytoalexins) often are produced (Dixon 1986) and the cell wall is strengthened as a result of lignification and the cross-linking of cell wall proteins (Bowles 1990; Bradley et al. 1992; Brisson et al. 1994). In addition to the HR, the uninfected portion of the plant develops increased resistance to a secondary infection by even unrelated pathogens. This nonspecific resistance is known as systemic acquired resistance (SAR; Chester 1933; Ross 1961; Ryals et al. 1996) and it is associated with the systemic expression of SAR genes, which include several families of pathogenesis-related $(P R)$ genes (Ward et al. 1991). In addition to serving as molecular markers for SAR, several of the PR proteins have been shown to have activity against pathogens in vitro and/or in vivo (Kombrink and Somssich 1997).

Still relatively little is known about the plant signal transduction pathways following pathogen infection that lead to the local and systemic activation of defense responses, such as $P R$ gene expression. However, numerous studies have demonstrated that salicylic acid (SA) is an important component of one or more of these pathways. It has long been known that treating tobacco leaves with SA enhances resistance to tobacco mosaic virus (TMV; White 1979). In addition, SA induces the same or similar set of SAR genes as those expressed during a resistance response to pathogens (Ward et al. 1991). Furthermore, SA levels increase after infection with an avirulent pathogen in tobacco, cucumber, and Arabidopsis (Dempsey et al. 1997; Enyedi et al. 1992; Malamy et al. 1990, 1992; Métraux et al. 1990; Uknes et al. 1993; Mauch-Mani and Slusarenko 1996). In tobacco and Arabidopsis, this increase in SA precedes or coincides with $P R$ gene expression. Some of the strongest evidence that SA plays a role in resistance comes from studies of transgenic tobacco and Arabidopsis plants expressing a salicylate hydroxylase-encoding 
(nahG) gene from Pseudomonas putida. Salicylate hydroxylase converts SA to catechol; thus, plants expressing the $n a h G$ gene are unable to accumulate SA at high levels. Strikingly, these NahG plants fail to develop SAR and exhibit enhanced susceptibility to pathogen infection (Delaney et al. 1994; Gaffney et al. 1993).

To further characterize the resistance signal transduction pathway, several laboratories have isolated Arabidopsis mutants that exhibit altered responses to pathogen infection. Some of these mutants are more susceptible to pathogen infection and fail to express defense genes after SA treatment. In contrast, other mutants are more resistant to pathogens. This latter group can be further divided into three classes. One class spontaneously forms HR-like lesions and concurrently exhibits increases in $P R$ gene expression and endogenous SA levels. Included in this class are the $\operatorname{acd} 2$ (accelerated cell death; Greenberg et al. 1994), cpr5 (constitutive expressor of $\underline{P R}$ genes; Bowling et al. 1997), ssil (suppressor of $\underline{\mathrm{S} A-i n s e n-}$ sitivity of nprl-5; Shah et al. 1999), and lsd (lesion simulating disease resistance; Dietrich et al. 1994; Weymann et al. 1995) mutants. The second class of mutants does not form spontaneous HR-like lesions but constitutively expresses $P R$ genes and contains elevated levels of SA. Examples of this class are the cprl (Bowling et al. 1994), cim3 (constitutive immunity; Ryals et al. 1996), and $d n d l$ (defense with no HR cell death; $\mathrm{Yu}$ et al. 1998) mutants. The last class of mutants confer pathogen resistance in the absence of constitutive $P R$ gene expression, e.g., edrl (enhanced disease resistance; Frye and Innes 1998).

In order to identify other components in the resistance signal transduction pathway, we have screened a collection of TDNA tagged lines from Arabidopsis thaliana (ecotype Wassilewskija [Ws]; Feldmann 1992) for mutants that constitutively express the $P R-1$ gene. Here we describe the isolation and characterization of a new mutant, cep, that exhibits constitutive expression of the $P R-1, P R-2$, and $P R-5$ genes, contains high endogenous levels of SA, spontaneously forms lesions, and shows enhanced resistance to both the bacterial pathogen Pseudomonas syringae pv. maculicola and the fungal pathogen Peronospora parasitica isolate EMWA. Genetic analyses indicate that the cep phenotype in our mutant is due to at least two recessive, unlinked mutations that we have termed cpr20 and cpr21, following the nomenclature of Bowling et al. (1994).

\section{RESULTS}

\section{Identification of the cep mutant.}

To date, the majority of mutants exhibiting enhanced disease resistance phenotypes (constitutive SAR mutants) were generated with the chemical mutagen ethylmethane sulfonate (Ryals et al. 1996). However, isolation of the resulting mutant genes requires map-based cloning. Because cloning with this approach is time-consuming and laborious we have screened a collection of T-DNA-containing mutants generated by Agrobacterium-mediated transformation of Arabidopsis seeds. Some of the resultant mutations are due to T-DNA insertion events (Feldmann et al. 1992) and, thus, the T-DNA can be used as a convenient tag for the rapid cloning of the mutated gene. Because $P R-1$ gene induction is an excellent molecular marker for activation of defense responses in Arabidopsis, as well as tobacco, we screened the T-DNA-containing collection of Ws-derived lines for constitutively high levels of $P R-1$ mRNA. Titration analysis with RNA prepared from untreated and SA-treated Arabidopsis plants indicated that we should be able to use Northern (RNA) blot analysis to detect a single mutant plant constitutively accumulating high levels of $P R-1$ transcript in a pool of 20 plants. A total of 3,000 lines were screened by repeated sowing of 60 seeds (representing 20 lines) in three pools of 20 seeds each. These plants were grown with a 14 -h light cycle $\left(140 \mu \mathrm{E} \mathrm{s}^{-1} \mathrm{~m}^{-2}\right)$ at $22^{\circ} \mathrm{C}$. One leaf was excised from each of the 203 -week-old plants in the pool, then combined and used for preparation of RNA and Northern analysis. Any pool that exhibited elevated levels of $P R-1$ transcript, compared with the wild-type (wt; Ws) control, was further analyzed by separately extracting RNA from each plant in the pool. Through this screening process one mutant called cep was identified.

In addition to constitutively expressing the $P R-1$ gene, cep plants displayed a variety of abnormal phenotypes. These included curly leaves, a slower growth rate, and stunted size at all stages of development, compared with wt plants. Interestingly, the cotyledons of cep plants prematurely senesced, and were completely necrotic by 18 days post planting (dpp). Close examination indicated that necrotic lesions began to appear by $10 \mathrm{dpp}$ on the cotyledons. This time correlates with the beginning of constitutive expression of $P R$ genes (data not shown).

\section{$P R$ genes are constitutively expressed in cep plants.}

To analyze the expression of $P R$ genes, Northern analysis was performed on individual 3-week-old cep and wt plants. As expected, the cep plants exhibited constitutive expression of the $P R-1$ gene (Fig. 1). In addition, these plants constitutively accumulated transcripts for the $P R-2$ and $P R-5$ genes. By contrast, little or no $P R$ gene expression was detected in any of the wt plants. The pattern of $P R$ gene expression in cep plants resembles that observed in SA-treated plants, with $P R-1$ transcript accumulating to high levels, and $P R-2$ and $P R-5$ transcripts accumulating to somewhat lower levels.

\section{Endogenous levels of free SA and SAG are elevated in cep plants.}

SA treatment is known to induce $P R$ gene expression in a wide variety of plants and SA levels precede or parallel the

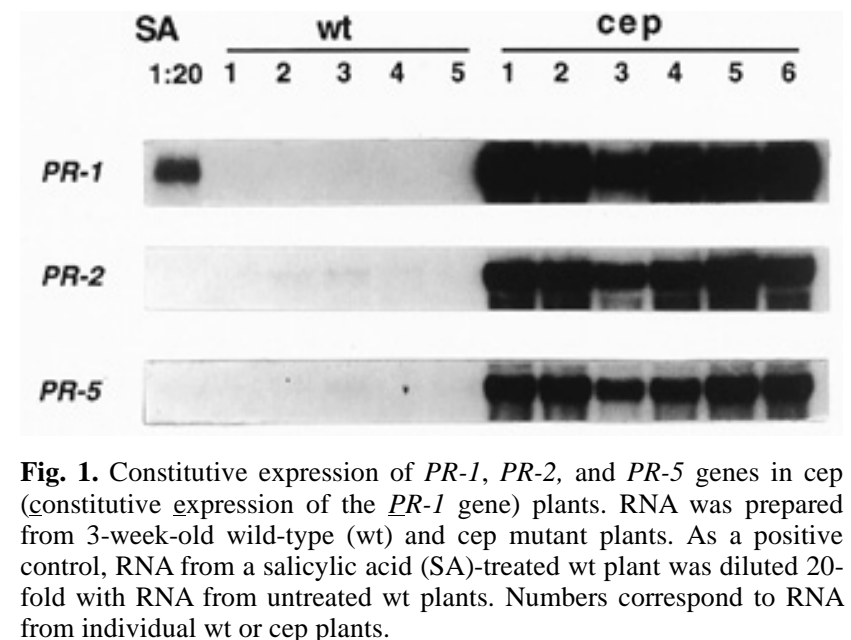
from individual wt or cep plants. 
induction of $P R-1$ genes in tobacco and Arabidopsis plants resisting infection by either TMV (Malamy et al. 1990, 1992) or turnip crinkle virus (Dempsey et al. 1997), respectively. Thus, the high level of $P R$ gene expression in cep plants raised the possibility that this mutation might affect endogenous SA levels. To assess this possibility, endogenous levels of free SA and SA glucoside (SAG) were monitored in cep and wt plants. cep plants were found to contain an eightfold higher basal level of SA and a sevenfold higher level of SAG than those detected in wt plants in the absence of any inducer (Fig. 2).

\section{The cep mutant develops spontaneous lesions.}

Several of the Arabidopsis mutants that exhibit enhanced disease resistance also spontaneously form lesions (Ryals et al. 1996). These spontaneous lesions exhibit characteristics similar to a pathogen-induced HR, such as the accumulation of cell-wall-associated autofluorescent material (Lummerzheim et al. 1993; Yu et al. 1993). cep plants also were observed to form spontaneous lesions. Initially, these lesions appeared on the cotyledons approximately $10 \mathrm{dpp}$. Over time, the size of the lesions increased and by $18 \mathrm{dpp}$ the cotyledons were completely necrotic. To determine whether the spontaneous lesions formed on cep cotyledons are associated with the accumulation of autofluorescent compounds, we performed microscopic analysis on 10-day-old cotyledons from cep and wt plants. On the cep cotyledons, the cells associated with the spontaneous lesions exhibited yellow autofluorescence around their perimeter (Fig. 3A). These cells also were irregularly shaped, suggesting some loss of internal structure. In contrast, no accumulation of cell-wall-associated fluorescent material was detected on the cotyledons of wt plants (Fig. 3B). Spontaneous lesions also formed on some of the true leaves of cep plants by 3 weeks post planting. They appeared as localized necrotic spots and exhibited limited expansion. Necrosis was also evident on some of the petioles of 4-weekold cep plants. Interestingly, lesions formed by cep plants were not suppressed by short day length, in contrast to those associated with several $l s d$ mutants (Dietrich et al. 1994).
SA

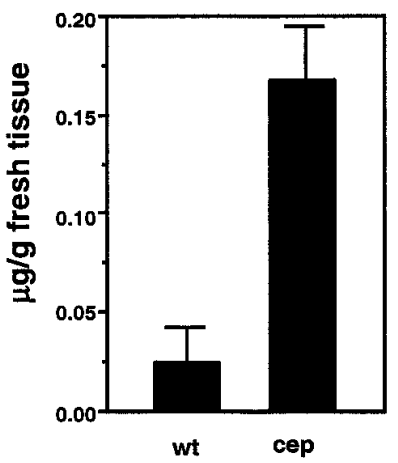

SAG

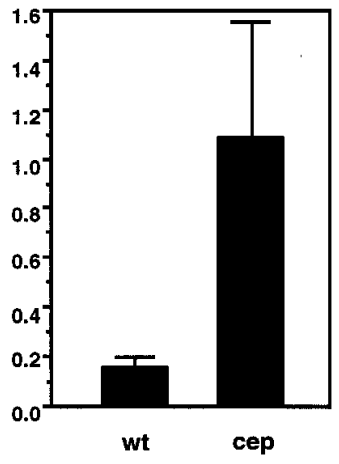

Fig. 2. Endogenous levels of free salicylic acid (SA) and SA glucoside (SAG) in wild-type (wt) and cep (constitutive expression of the $\underline{P} R-1$ gene) plants. Leaves from 3-week-old wt and cep plants were harvested for SA and SAG analyses. Values presented for free SA and SAG (conjugated form) are the average for each of three different sets of samples with standard deviation. This experiment was done twice with similar results. cep plants are resistant to the virulent pathogens Pseudomonas syringae pv. maculicola and Peronospora parasitica isolate EMWA.

To determine whether cep plants exhibit enhanced disease resistance, we analyzed the growth of two virulent strains of Pseudomonas syringae pv. maculicola (M4 and M5) in cep plants. Five-week-old plants were infected with either of these strains and bacterial growth and disease symptoms were monitored for several days post inoculation (dpi). Chlorosis was observed at 3 dpi in wt plants, whereas few, if any, symptoms were observed in cep plants (data not shown). While both strains of bacteria multiplied in the wt and cep plants, their growth in cep plants was consistently lower than in wt plants at all the times assayed. This difference was more evident between 3 and 5 dpi for both strains (Fig. 4).

To investigate whether cep plants exhibit enhanced resistance to other types of pathogens, we monitored the growth of Peronospora parasitica isolate EMWA, a fungal pathogen that is virulent on the Ws ecotype. Three-week-old plants were infected and sporulation and disease symptoms were monitored. At $6 \mathrm{dpi}$, conidiophores were observed on the leaves of all wt plants. In contrast, conidiophores were absent in almost all of the cep plants (Table 1). By $14 \mathrm{dpi}$, all the wt plants were chlorotic and wilted. By contrast, the cep plants did not show any of these symptoms.

The cep phenotype in Ws is conditioned by a single recessive mutation.

To analyze the genetic nature of cep, a backcross was performed between cep plants and Ws wt plants and the resultant progeny were monitored for constitutive $P R-1$ gene expression. In the $\mathrm{F}_{1}$ generation, none of the 14 plants tested exhibited constitutive $P R-1$ gene expression, suggesting that the cep trait is recessive (Table 2). The $\mathrm{F}_{2}$ plants were also scored for constitutive expression of $P R-1$. Out of 430 plants, 95 exhibited constitutive $P R$ expression; this approximate ratio of 1 constitutive for $P R$ expression : $3 \mathrm{wt}\left(X^{2}=1.79 ; 0.5>P>0.1\right)$ confirms that the cep phenotype in our original mutant is due to a recessive mutation in a single nuclear gene. Several cepassociated morphological abnormalities, including curly leaves, necrotic cotyledons, and stunted growth, were observed to segregate with the constitutive expression of the $P R$ 1 gene. Thus, these morphologies were either caused by the cep mutation or by another, tightly linked mutation.

\section{The cep phenotype in Col-0 or Ler plants appears} to require recessive mutations at more than one locus.

Surprisingly, when cep plants were crossed with those of a different ecotype (i.e., Columbia; Col-0), a deviation from the expected ratio of constitutive $P R$ expressing to wt progeny was observed in the $F_{2}$ generation. None of $10 F_{1}$ progeny plants tested exhibited constitutive expression of $P R-1$, confirming the recessive nature of the mutation (Table 2). However, in the $\mathrm{F}_{2}$ generation, only 34 plants out of 648 total exhibited constitutive $P R$ expression. This ratio $\left(1: 17 ; X^{2}\right.$ $[$ monofactorial $]=134, P<0.001 ; X^{2}[$ bifactorial $]=2.01,0.5$ $>P>0.1$ ) could indicate that the cep phenotype is controlled by two independent nuclear loci. Alternatively, the cep phenotype may have a low penetrance in the Ws/Col-0 hybrid background, i.e., not just one but rather a host of modifiers could affect the expression of this phenotype. Similar results were observed in crosses between cep plants and those from 
the Landsberg erecta (Ler) ecotype (data not shown). The fact that our initial analysis with Ws plants revealed only one locus suggests that, in this background, the allele(s) at the other locus (loci) does (do) not interfere with the expression of the cep phenotype. Thus, in order to fully characterize this phenotype, we continued to analyze it in plants from the Ws background.

To determine whether the newly arisen mutation is tagged by a T-DNA insert, $14 \mathrm{~F}_{1}$ plants from a cross between cep and wt (Ws ecotype) were monitored for resistance to kanamycin (Table 3). All 14 plants were kanamycin resistant. These plants were allowed to self-pollinate and kanamycin resistance was tested in $136 \mathrm{~F}_{2}$ progeny. A ratio of 3 kanamycin-resistant plants : 1 kanamycin-sensitive plant was observed, indicating the presence of a single locus containing one or more T-DNA inserts (Table 3). This was confirmed by Southern blot analysis with the left and right borders of the T-DNA inserts as probes (data not shown). An additional pool of $F_{2}$ plants (derived from the same $F_{1}$ parent) was screened for the curly leaves and necrotic cotyledons associated with the cep phenotype. A total of 88 putative cep mutants were identified and their cep phenotype was confirmed by analyzing $P R$ gene expression. These 88 plants were allowed to self-pollinate and approximately $50 \mathrm{~F}_{3}$ progeny from each line were tested for kanamycin resistance. If the cep phenotype were due to the T-

A

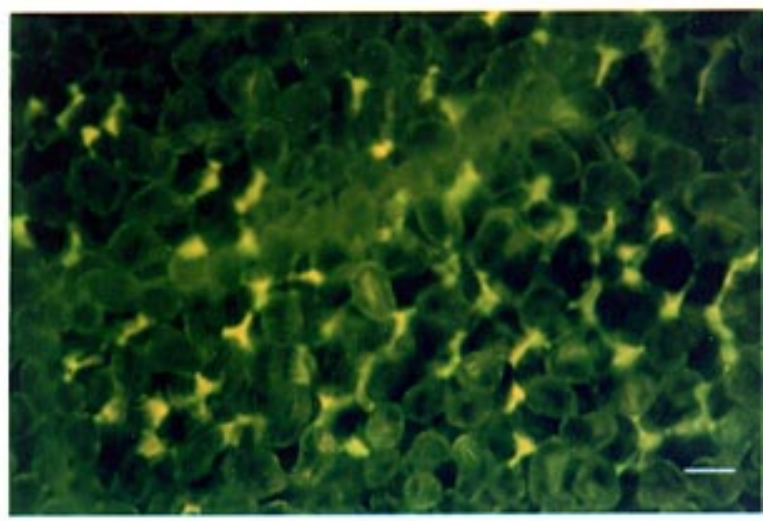

B

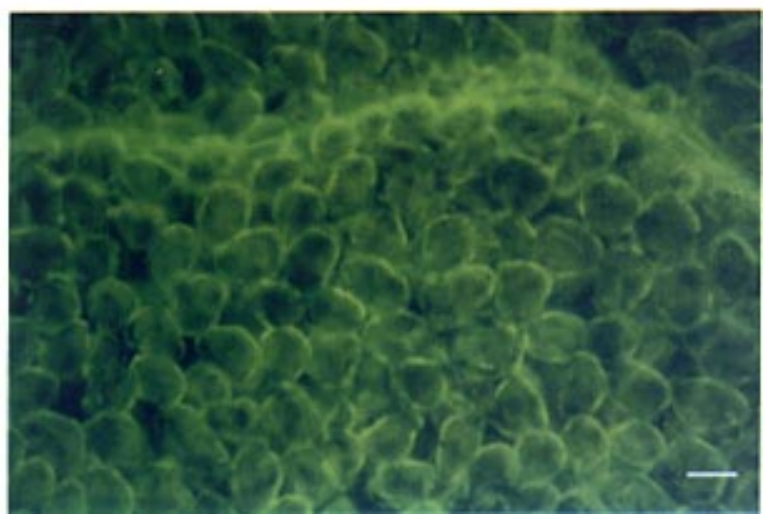

Fig. 3. Accumulation of autofluorescent cell wall material in (A) cep (constitutive expression of the $\underline{P} R-1$ gene) and (B) wild-type (wt) plants. Cotyledons from 10-day-old cep and wt plants were used for microscopic observation. Bars $=49 \mu \mathrm{m}$.

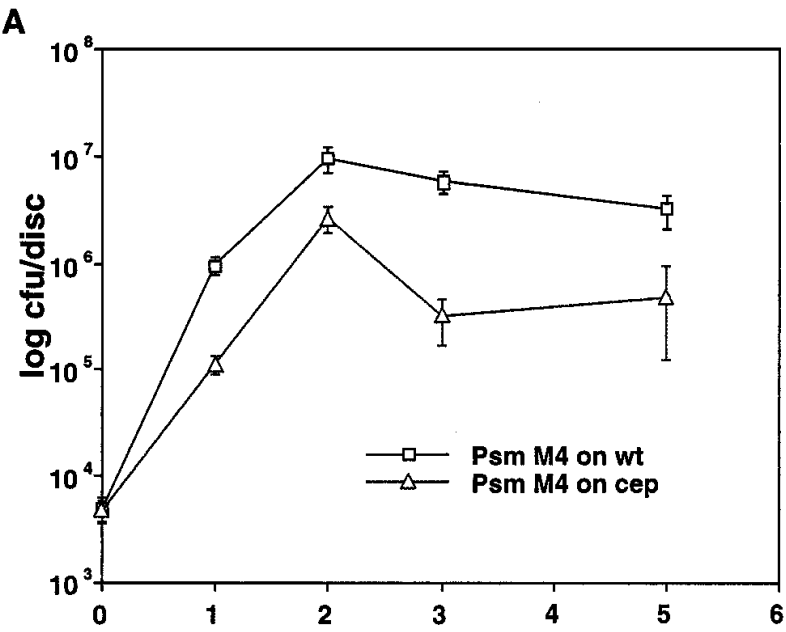

B

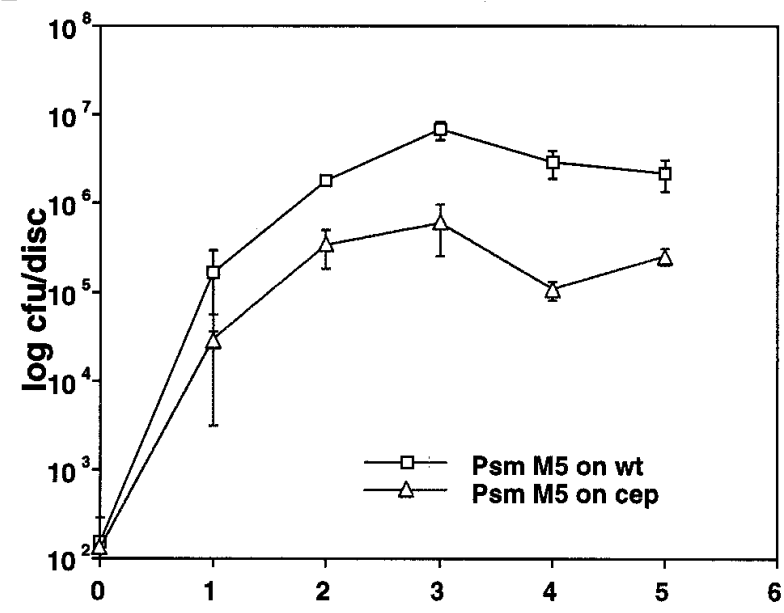

Days after inoculation

Fig. 4. Growth of Pseudomonas syringae pv. maculicola (Psm) strains (A) M4 and (B) M5 in wild-type (wt) and cep (constitutive expression of the $\underline{P} R-1$ gene) plants. Bacterial strains M4 $\left(10^{5} \mathrm{CFU} \mathrm{m}{ }^{-1}\right)$ and M5 $\left(10^{4} \mathrm{CFU} \mathrm{ml}{ }^{-1}\right)$ were suspended in $10 \mathrm{mM} \mathrm{MgCl}_{2}$ and injected in the abaxial surface of 12 leaves per time point. CFU of M4 and M5 per leaf disk $\left(0.28 \mathrm{~cm}^{2}\right)$ were determined at various time points (days) after inoculation as described in Materials and Methods. Values represent average and standard deviation calculated from four samples containing three leaf disks each. This experiment was done three times with similar results.

Table 1. Peronospora parasitica isolate EMWA-induced disease

\begin{tabular}{lrrrrr}
\hline & \multicolumn{5}{c}{ Number of plants expressing disease levels ${ }^{\mathbf{a}}$} \\
\cline { 2 - 6 } Plants $^{\mathbf{b}}$ & $\mathbf{0}$ & + & ++ & +++ & Total plants $^{+}$ \\
Wild type & 0 & 0 & 6 & 160 & 166 \\
cep & 158 & 4 & 4 & 0 & 166 \\
\hline
\end{tabular}

${ }^{a}$ Scale for level of disease: 0 , no conidiophores on plant; + , at least one leaf with one to five conidiophores; ++, many leaves with five to twenty conidiophores; +++, all inoculated leaves with more than 20 conidiophores. All plants were scored at 6 days post inoculation.

${ }^{\mathrm{b}}$ All plants are from the Wassilewskija (Ws) ecotype. cep $=$ constitutive expression of the $\underline{P} R-1$ gene. 
DNA insertion, the progeny of all 88 families should be uniformly kanamycin resistant. However, only 11 were uniformly kanamycin resistant (Table 3), indicating that the new mutation is unlinked to the T-DNA.

\section{The cep phenotype is suppressed in NahG plants.}

The high endogenous levels of SA and SAG in cep plants suggested that the CEP gene product(s) might act upstream of $\mathrm{SA}$ in the pathway leading to $P R$ gene expression. To confirm this, we crossed homozygous cep plants with a homozygous transgenic Ler line expressing the $n a h G$ gene (Bowling et al. 1994). Analysis of the resultant progeny showed that none of the $\mathrm{F}_{1}$ plants expressed the $P R-1$ gene constitutively, as expected of a recessive trait (Table 2). In the $\mathrm{F}_{2}$ generation, different ratios of cep to wt plants could be predicted, depending on the number of factors that control the cep phenotype in the

Table 2. Genetic and complementation analyses

\begin{tabular}{|c|c|c|c|c|c|c|c|c|}
\hline \multirow[b]{3}{*}{ Cross $^{a}$} & \multirow{3}{*}{$\begin{array}{l}\text { Gen- } \\
\text { era- } \\
\text { tion }\end{array}$} & \multirow[b]{3}{*}{ Total } & \multicolumn{4}{|c|}{$P R-1$ expression } & \multirow[b]{3}{*}{$X^{2}$} & \multirow[b]{3}{*}{$P$} \\
\hline & & & \multicolumn{2}{|c|}{$\begin{array}{c}\text { Consti- } \\
\text { tutive }\end{array}$} & \multicolumn{2}{|c|}{$\begin{array}{l}\text { Not con- } \\
\text { stitutive }\end{array}$} & & \\
\hline & & & $\mathbf{O}^{\mathbf{b}}$ & $\overline{\mathbf{E}^{\mathbf{b}}}$ & $\mathbf{O}$ & $\mathbf{E}$ & & \\
\hline Ws cep $\times$ Ws wt & $\begin{array}{l}\mathrm{F}_{1} \\
\mathrm{~F}_{2}\end{array}$ & $\begin{array}{c}14 \\
430\end{array}$ & $\begin{array}{c}0 \\
95\end{array}$ & $\begin{array}{c}0 \\
107\end{array}$ & $\begin{array}{c}14 \\
335\end{array}$ & $\begin{array}{c}14 \\
323\end{array}$ & $1.79^{\mathrm{c}}$ & $>0.1$ \\
\hline Ws cep $\times$ Col- 0 wt & $\begin{array}{l}F_{1} \\
F_{2}\end{array}$ & $\begin{array}{c}10 \\
648\end{array}$ & $\begin{array}{c}0 \\
34\end{array}$ & $\begin{array}{c}0 \\
41\end{array}$ & $\begin{array}{c}10 \\
614\end{array}$ & $\begin{array}{c}10 \\
607\end{array}$ & $1.28^{\mathrm{d}}$ & $>0.1$ \\
\hline Ws cep $\times$ Ler $n a h G$ & $\begin{array}{c}n a h G \\
\mathrm{~F}_{1} \\
\mathrm{~F}_{2}\end{array}$ & $\begin{array}{c}10 \\
837\end{array}$ & $\begin{array}{l}0 \\
8\end{array}$ & $\begin{array}{c}0 \\
-{ }^{e}\end{array}$ & $\begin{array}{c}10 \\
829\end{array}$ & $\begin{array}{l}10 \\
-{ }^{\mathrm{e}}\end{array}$ & & \\
\hline Ws cep $\times$ Col- $0 \mathrm{cpr}$ & $\begin{array}{c}1 / \text { cprl } \\
\mathrm{F}_{1} \\
\mathrm{~F}_{2}\end{array}$ & $\begin{array}{c}6 \\
137\end{array}$ & $\begin{array}{c}0 \\
26\end{array}$ & $\begin{array}{c}6 \\
137\end{array}$ & $\begin{array}{c}6 \\
111\end{array}$ & $\begin{array}{l}0 \\
0\end{array}$ & & \\
\hline Ws cep $\times$ Col- 0 cpr & $\begin{array}{c}5 / c p r 5 \\
\mathrm{~F}_{1} \\
\mathrm{~F}_{2}\end{array}$ & $\begin{array}{c}6 \\
41\end{array}$ & $\begin{array}{c}0 \\
15\end{array}$ & $\begin{array}{c}6 \\
41\end{array}$ & $\begin{array}{c}6 \\
26\end{array}$ & $\begin{array}{l}0 \\
0\end{array}$ & & \\
\hline Ws cep $\times$ Col-0 $a c$ & $\begin{array}{l}2-2 / a c d \\
\mathrm{~F}_{1}\end{array}$ & $\begin{array}{r}12-2 \\
5\end{array}$ & 0 & 5 & 5 & 0 & & \\
\hline $\begin{array}{l}{ }^{\mathrm{a}} \text { Genotype of the } \mathrm{p} \\
\text { pollen donor seco } \\
\text { berg erecta; cep, } \mathrm{c} \\
{ }^{\mathrm{b}} \mathrm{O} \text {, observed; } \mathrm{E} \text {, ex } \\
{ }^{\mathrm{c}} X^{2} \text { calculation bas } \\
{ }^{\mathrm{d}} X^{2} \text { calculation bas } \\
{ }^{\mathrm{e}} \text { No expected value }\end{array}$ & $\begin{array}{l}\text { len ac } \\
1 . \text { Ws } \\
\text { stitut } \\
\text { ected. } \\
\text { on a } \\
\text { on a } \\
\text { s pro }\end{array}$ & $\begin{array}{l}\text { ceptin } \\
\text { Wass } \\
\text { ive ex } \\
1: 3 \mathrm{rat} \\
1: 15 \mathrm{ra} \\
\text { vided a }\end{array}$ & & $\begin{array}{l}\text { indi } \\
\mathrm{Col} \\
\text { f the }\end{array}$ & $\begin{array}{l}-0, C \\
\underline{P} R\end{array}$ & $\begin{array}{l}\text { rst an } \\
\text { Imbia } \\
\text { ene. }\end{array}$ & 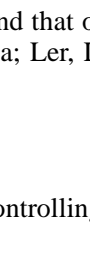 & $\begin{array}{l}\text { f the } \\
\text { ans- } \\
\text { the }\end{array}$ \\
\hline
\end{tabular}

cep $\times$ Ler intercross (see previous section). However, one prediction can be made with certainty. If the $n a h G$ gene product suppresses the cep phenotype, none of the mutant plants segregating in the $\mathrm{F}_{2}$ should carry this gene. Alternatively, if expression of the cep phenotype is independent of the $n a h G$ product, $3 / 4$ of the mutant plants should carry the nahG gene in either the homozygous or heterozygous condition. In the $\mathrm{F}_{2}$ population, only 8 of 837 plants exhibited constitutive $P R-1$ gene expression, stunted growth, and spontaneous lesion formation (Table 2). None of these 8 plants accumulated $n a h G$ transcript (data not shown), confirming that they lack the $n a h G$ transgene. The probability that, by chance alone, none of the 8 cep plants would have received at least one copy of the $n a h G$ transgene is $(1 / 4)^{8}$ or $1.5 \times 10^{-5}$. These observations support the notion that the $n a h G$ gene product suppresses the cep phenotype and that the only plants with a cep phenotype that can be recovered in the segregating population are those that lack the $n a h G$ transgene. We conclude from these data that CEP functions upstream of SA in the $P R$ gene induction pathway.

\section{The cep phenotype is not expressed in outcrosses to $c p r 1$, cpr5, and acd2.}

Like cep, mutants carrying either $c p r 1, c p r 5$, or acd2 (Col-0 ecotype) constitutively express the $P R-1, P R-2$, and $P R-5$ genes and exhibit enhanced disease resistance to various pathogens. In addition, the $c p r 5$ and $a c d 2$ plants develop spontaneous lesions. To test for complementation of the constitutive phenotypes conditioned by these recessive mutations, cep plants were crossed to cprl, cpr5, and acd 2 plants. For all three crosses, the $F_{1}$ progeny failed to constitutively express the $P R-1$ gene or develop any of the morphological abnormalities associated with the different mutants (Table 2). The most likely interpretation of these results is that the cep phenotype is not due to a mutation in any of the above genes.

\section{Mapping of mutation(s) producing the cep phenotype.}

In order to map the mutation(s) responsible for the cep phenotype, we crossed Ws cep plants with Col-0 wt plants. As expected for a recessive trait, the $\mathrm{F}_{1}$ progeny did not exhibit constitutive $P R-1$ gene expression or the curly leaves and stunted growth morphology associated with cep (data not shown). These plants were allowed to self-pollinate and the $F_{2}$ progeny were screened for plants exhibiting curly leaves and stunted growth. Seventy-nine such plants were identified. To confirm the cep phenotype of these plants, $\mathrm{F}_{3}$ progeny derived

Table 3. Segregation analysis of the cep phenotype and kanamycin resistance

\begin{tabular}{|c|c|c|c|c|c|c|c|c|c|c|}
\hline \multirow[b]{3}{*}{ Cross $^{\mathrm{a}}$} & \multirow[b]{3}{*}{ Generation } & \multirow[b]{3}{*}{ Total } & \multicolumn{4}{|c|}{ Kanamycin resistance } & & & \multirow[b]{3}{*}{ Hypothesis } & \multirow[b]{3}{*}{ Fit? } \\
\hline & & & \multicolumn{2}{|c|}{ Resistant } & \multicolumn{2}{|c|}{ Segragating } & \multicolumn{2}{|c|}{ Sensitive } & & \\
\hline & & & $\mathbf{O}^{\mathbf{b}}$ & $\mathbf{E}^{\mathbf{b}}$ & $\mathbf{O}$ & $\mathbf{E}$ & $\mathbf{O}$ & $\mathbf{E}$ & & \\
\hline \multirow[t]{3}{*}{ Ws cep $\operatorname{kan}^{\mathrm{r}} \times$ Ws wt } & $\mathrm{F}_{1}$ & 14 & 14 & $14^{\mathrm{c}}$ & & & 0 & $0^{\mathrm{v}}$ & & \\
\hline & $\mathrm{F}_{2}$ & 136 & 102 & 102 & & & 34 & 34 & & \\
\hline & $\mathrm{F}_{3}$ & $88^{\mathrm{d}}$ & 11 & $88^{\mathrm{e}}$ & 30 & $0^{\mathrm{e}}$ & 47 & $0^{\mathrm{e}}$ & T-DNA & NO \\
\hline \multicolumn{11}{|c|}{$\begin{array}{l}\text { The pollen accepting plant is indicated first and th } \\
\text { namycin resistance marker; wt, wild type. } \\
\text { b O, observed; E, expected. } \\
{ }^{\mathrm{c}} \text { Expected for the dominant kan }{ }^{\mathrm{r}} \text { selectable marker. }\end{array}$} \\
\hline
\end{tabular}


by selfing the 79 individual $\mathrm{F}_{2}$ plants were tested for constitutive $P R-1$ gene expression. The chromosomal location of the mutation(s) responsible for the cep phenotype in this segregating population was then mapped with the $79 \mathrm{~F}_{2}$ plants and a variety of CAPS (cleaved co-dominant amplified polymorphic sequences; Konieczny and Ausubel 1993) and SSLP (single sequence length polymorphism; Bell and Ecker 1994) markers (Table 4). Because these markers are co-dominant, the genotype for all 158 chromosomes could be monitored at every locus tested. Through this analysis it was determined that a mutation necessary for expression of the cep phenotype maps to the lower arm of chromosome 4, approximately $2.5 \mathrm{cM}$ north of nga1107 and $4.5 \mathrm{cM}$ south of PAP7.2. We have designated this mutation cpr20. This most likely corresponds to the new mutation identified in the T-DNA-mutagenized Ws population.

Among the 79 cep $F_{2}$ plants, the segment of chromosome 1 between nga280 and $\beta$-fructosidase gene was homozygous Ws in 62 , heterozygous in 9 , and homozygous Col-0 in 8 . This chromosome segment segregated in the expected Mendelian ratio within a random sample of wt $F_{2}$ segregants examined (data not shown), confirming that the strong deviation from expectation seen among the cep segregants was not due to abnormal transmission of the Col-0 markers. These data indicate that a second Ws-derived factor in chromosome 1 is often, but not always, associated with expression of the mutant phenotype in the $\mathrm{F}_{2}$ segregants of a Ws cep $\times$ Col- 0 wt cross. We have designated this factor $c p r 21$. The simplest interpretation of the $\mathrm{F}_{2}$ segregation data is that the normal $C P R 20$ and $C P R 21$ genes specify redundant functions.

\section{DISCUSSION}

In an effort to identify new components in the resistance signaling pathway, we screened T-DNA-mutagenized Arabidopsis thaliana plants for mutants exhibiting constitutive expression of defense responses. Through this process, a mutant that constitutively expresses the $P R-1, P R-2$, and $P R-5$ genes was isolated (Fig. 1) and named cep. These plants also de-

Table 4. CAPS (cleaved co-dominant amplified polymorphic sequences) and SSLP (single sequence length polymorphism) analysis of cep mutant

\begin{tabular}{|c|c|c|c|c|c|c|c|c|c|c|}
\hline \multirow[b]{2}{*}{ Plant no. ${ }^{a}$} & \multicolumn{6}{|c|}{ Chromosome 1} & \multicolumn{4}{|c|}{ Chromosome 4} \\
\hline & nga280 & $\beta$-fructosidase & Nim & mi424 & $\operatorname{mi185}$ & nga111 & nga1139 & AP2.3 & PAP72.1 & nga1107 \\
\hline 18 & $\mathrm{H}^{\mathrm{b}}$ & $\mathrm{H}$ & $\mathrm{H}$ & $\mathrm{H}$ & $\mathrm{H}$ & $\mathrm{H}$ & $\mathrm{W}$ & $\mathrm{W}$ & $\mathrm{W}$ & $\mathrm{W}$ \\
\hline 19 & $\mathrm{~W}^{\mathrm{c}}$ & W & $\mathrm{H}$ & $\mathrm{H}$ & $\mathrm{H}$ & $\mathrm{H}$ & W & W & W & W \\
\hline 52 & W & W & W & $\mathrm{H}$ & $\mathrm{H}$ & $C^{d}$ & W & W & W & $\mathrm{H}$ \\
\hline 53 & W & W & W & $\mathrm{W}$ & $\mathrm{W}$ & $\mathrm{W}$ & W & W & W & $\mathrm{W}$ \\
\hline 85 & $\mathrm{H}$ & $\mathrm{H}$ & $\mathrm{H}$ & $\mathrm{H}$ & $\mathrm{H}$ & $\mathrm{H}$ & $\mathrm{H}$ & W & W & W \\
\hline 86 & W & W & W & W & W & $\mathrm{H}$ & W & W & W & W \\
\hline 89 & W & W & W & W & W & W & W & W & W & $\mathrm{H}$ \\
\hline 111 & W & W & W & W & W & $\mathrm{H}$ & W & W & W & W \\
\hline 119 & W & W & W & W & $\mathrm{H}$ & $\mathrm{H}$ & W & W & W & W \\
\hline 130 & $\mathrm{H}$ & W & W & W & W & W & W & W & W & $\mathrm{H}$ \\
\hline 136 & W & W & W & W & W & W & W & W & W & W \\
\hline 138 & $\mathrm{H}$ & $\mathrm{H}$ & $\mathrm{H}$ & $\mathrm{H}$ & W & W & W & W & W & W \\
\hline 151 & $\mathrm{H}$ & $\mathrm{H}$ & $\mathrm{H}$ & $\mathrm{H}$ & $\mathrm{H}$ & W & W & W & W & W \\
\hline 197 & W & W & W & W & W & W & W & W & W & W \\
\hline 213 & W & W & W & W & W & W & W & W & W & W \\
\hline 225 & W & W & W & W & W & W & W & W & W & W \\
\hline 233 & W & W & W & W & W & W & $\mathrm{H}$ & W & W & W \\
\hline 257 & W & W & W & W & W & W & W & W & W & W \\
\hline 303 & $\mathrm{H}$ & $\mathrm{H}$ & $\mathrm{H}$ & $\mathrm{H}$ & $\mathrm{H}$ & W & $\mathrm{H}$ & $\mathrm{H}$ & $\mathrm{H}$ & W \\
\hline 311 & W & W & W & W & W & W & W & W & W & W \\
\hline 332 & $\mathrm{H}$ & W & W & W & $\mathrm{H}$ & $\mathrm{H}$ & W & W & W & W \\
\hline 347 & W & W & W & W & W & W & W & W & W & W \\
\hline 348 & W & W & W & W & W & W & W & W & W & W \\
\hline 371 & W & W & W & W & W & W & W & W & W & W \\
\hline 372 & W & W & W & W & W & $\mathrm{H}$ & W & W & W & W \\
\hline 383 & W & W & W & W & W & W & W & W & W & W \\
\hline 386 & W & W & $\mathrm{H}$ & $\mathrm{H}$ & $\mathrm{H}$ & $\mathrm{H}$ & W & W & W & $\mathrm{H}$ \\
\hline 393 & W & W & $\mathrm{W}$ & $\mathrm{W}$ & $\mathrm{H}$ & $\mathrm{C}$ & W & W & W & $\mathrm{W}$ \\
\hline 398 & W & W & W & W & $\mathrm{H}$ & W & W & W & W & $\mathrm{H}$ \\
\hline 405 & W & W & W & W & W & W & W & W & W & W \\
\hline 411 & W & W & $\mathrm{H}$ & $\mathrm{H}$ & $\mathrm{H}$ & $\mathrm{H}$ & W & W & W & W \\
\hline 416 & $\mathrm{C}$ & $\mathrm{C}$ & $\mathrm{C}$ & $\mathrm{C}$ & $\mathrm{C}$ & $\mathrm{C}$ & W & W & W & W \\
\hline $421-b$ & $\mathrm{~W}$ & $\mathrm{~W}$ & $\mathrm{H}$ & $\mathrm{H}$ & $\mathrm{H}$ & $\mathrm{H}$ & W & W & W & W \\
\hline 421-c & W & W & W & W & $\mathrm{H}$ & $\mathrm{H}$ & W & W & W & W \\
\hline 424-b & W & W & W & W & W & $\mathrm{H}$ & W & W & W & W \\
\hline $435-b$ & W & W & W & W & W & W & W & W & W & W \\
\hline
\end{tabular}

${ }^{a}$ All 79 plants analyzed exhibited the cep phenotype including curly leaves and stunted growth morphology and constitutive expression of the $\underline{P} R-1$ gene.

${ }^{\mathrm{b}}$ Heterozygous.

${ }^{\mathrm{c}}$ Homozygous Ws; Wassilewskija.

${ }^{\mathrm{d}}$ Homozygous Col-0; Columbia-0/

e Not determined. 
velop curly leaves and their growth is stunted, compared with wt plants. Interestingly, cep plants contained approximately eightfold higher levels of SA and SAG than those detected in wt plants (Fig. 2). Because SA appears to be a key component of the resistance signaling pathway, and endogenous SA levels increase in tobacco and Arabidopsis plants before or in parallel with the induction of $P R$ gene expression during the HR and SAR (Ryals et al. 1996; Durner et al. 1997; Yang et al. 1997), these elevated SA levels are probably responsible for the constitutive $P R$ gene expression observed in cep plants. This possibility was confirmed by the demonstration that both the morphological characteristics associated with the cep mutant (lesion formation, stunted growth, and curly leaves) and constitutive $P R$ gene expression were suppressed in the $\mathrm{F}_{2}$ progeny of a cross between cep and NahG plants (Table 2).

In addition to constitutively expressing several defense genes and containing elevated levels of SA, cep plants developed spontaneous lesions on their cotyledons and leaves. Microscopic analysis indicated that the deposition of auto- fluorescent cell wall material was associated with these lesions (Fig. 3). The nature of this autofluorescent material is not known. However, it is thought to be composed of crosslinked phenolic compounds, which might strengthen the cell wall (Schröder et al. 1992). The deposition of autofluorescent cell wall material has previously been associated with the HR and resistance in several plant-pathogen interactions (Dempsey et al. 1997; Lummerzheim et al. 1993; Schröder et al. 1992; Yu et al. 1993). Accumulation of autofluorescent compounds has also been documented in the spontaneous lesions developed by some of the previously described enhanced disease resistance mutants of Arabidopsis (Greenberg et al. 1994; Dietrich et al. 1994; Weymann et al. 1995). However, unlike the lesions formed by the $a c d 2$ and lsdl mutants, those developed by cep plants did not spread throughout the entire leaf. Furthermore, spontaneous lesion formation in cep plants was not environmentally regulated, whereas a specific day length was required to initiate lesion development in several of the $l s d$ mutants (Dietrich et al.

Table 4. (continued from preceding page)

\begin{tabular}{|c|c|c|c|c|c|c|c|c|c|c|}
\hline \multirow[b]{2}{*}{ Plant no. ${ }^{a}$} & \multicolumn{6}{|c|}{ Chromosome 1} & \multicolumn{4}{|c|}{ Chromosome 4} \\
\hline & nga280 & $\beta$-fructosidase & Nim & mi424 & $\operatorname{mi185}$ & nga111 & nga1139 & AP2.3 & PAP72.1 & nga1107 \\
\hline $437-a$ & $\mathrm{~W}$ & W & W & W & W & W & $\mathrm{W}$ & $\mathrm{W}$ & $\mathrm{W}$ & $\mathrm{W}$ \\
\hline 438 & $\mathrm{~W}$ & $\mathrm{~W}$ & W & $\mathrm{W}$ & W & W & W & $\mathrm{W}$ & $\mathrm{W}$ & W \\
\hline 445 & W & W & W & W & W & $\mathrm{H}$ & W & $\mathrm{W}$ & W & $\mathrm{W}$ \\
\hline 451 & W & W & W & $\mathrm{W}$ & $\mathrm{W}$ & W & W & $\mathrm{W}$ & $\mathrm{W}$ & W \\
\hline 458 & $\mathrm{H}$ & $\mathrm{H}$ & $\mathrm{H}$ & $\mathrm{H}$ & $\mathrm{H}$ & $\mathrm{H}$ & W & W & W & W \\
\hline 478-b & $\mathrm{C}$ & $\mathrm{C}$ & $\mathrm{C}$ & $\mathrm{C}$ & $\mathrm{H}$ & $\mathrm{H}$ & $\mathrm{H}$ & $\mathrm{H}$ & $\mathrm{H}$ & $\mathrm{W}$ \\
\hline 481 & W & W & W & W & W & W & W & $\mathrm{W}$ & W & $\mathrm{W}$ \\
\hline 485 & W & W & W & W & W & $\mathrm{W}$ & $\mathrm{H}$ & $\mathrm{W}$ & $\mathrm{W}$ & W \\
\hline 501 & W & W & W & W & W & $\mathrm{H}$ & $\mathrm{H}$ & W & W & W \\
\hline 502 & W & W & W & W & W & W & $\mathrm{H}$ & $\mathrm{H}$ & $\mathrm{H}$ & W \\
\hline 504 & W & W & W & W & W & $\mathrm{H}$ & W & W & W & W \\
\hline 507 & W & W & W & W & W & W & W & W & W & W \\
\hline 513 & $\mathrm{C}$ & $\mathrm{C}$ & $\mathrm{C}$ & $\mathrm{C}$ & $\mathrm{C}$ & $\mathrm{C}$ & $\mathrm{H}$ & W & $\mathrm{H}$ & W \\
\hline $526 a$ & $\mathrm{C}$ & $\mathrm{C}$ & $\mathrm{C}$ & $\mathrm{C}$ & $\mathrm{C}$ & $\mathrm{C}$ & $\mathrm{H}$ & W & W & W \\
\hline $526 b$ & $\mathrm{H}$ & $\mathrm{C}$ & $\mathrm{H}$ & $\mathrm{H}$ & $\mathrm{H}$ & $\mathrm{H}$ & $\mathrm{H}$ & $\mathrm{H}$ & $\mathrm{H}$ & W \\
\hline 530 & W & W & W & W & W & $\mathrm{H}$ & $\mathrm{C}$ & W & W & W \\
\hline 536 & W & W & W & W & W & W & $\mathrm{H}$ & W & W & W \\
\hline $539 a$ & W & W & W & W & W & W & W & W & W & W \\
\hline $539 b$ & W & W & W & W & W & W & W & W & W & W \\
\hline 543 & $\mathrm{H}$ & $\mathrm{H}$ & $\mathrm{H}$ & $\mathrm{H}$ & $\mathrm{H}$ & $\mathrm{H}$ & $\mathrm{H}$ & W & W & W \\
\hline 550 & W & W & W & W & W & W & W & W & W & W \\
\hline 551 & $\mathrm{C}$ & $\mathrm{C}$ & $\mathrm{C}$ & $\mathrm{C}$ & $\mathrm{C}$ & $\mathrm{C}$ & $\mathrm{H}$ & $\mathrm{H}$ & $\mathrm{H}$ & W \\
\hline 569 & W & W & W & W & W & $\mathrm{H}$ & W & W & W & W \\
\hline 574 & W & W & W & W & W & W & W & W & W & W \\
\hline 577 & W & W & W & W & W & W & W & W & W & W \\
\hline $591 \mathrm{a}$ & W & W & W & W & W & $\mathrm{H}$ & W & W & W & W \\
\hline $591 b$ & $\mathrm{C}$ & $\mathrm{C}$ & $\mathrm{C}$ & $\mathrm{C}$ & $\mathrm{C}$ & $\mathrm{C}$ & W & W & W & W \\
\hline $597 b$ & W & W & W & W & $\mathrm{H}$ & $\mathrm{H}$ & W & W & W & W \\
\hline 601 & $\mathrm{C}$ & $\mathrm{C}$ & $\mathrm{C}$ & $\mathrm{C}$ & $\mathrm{C}$ & $\mathrm{H}$ & $\mathrm{H}$ & $\mathrm{H}$ & $\mathrm{H}$ & W \\
\hline 606 & W & $\mathrm{H}$ & $\mathrm{H}$ & $\mathrm{H}$ & $\mathrm{H}$ & $\mathrm{H}$ & W & W & W & W \\
\hline 607 & W & W & W & W & W & W & W & W & W & W \\
\hline 610 & $\mathrm{H}$ & $\mathrm{H}$ & $\mathrm{H}$ & $\mathrm{H}$ & W & $\mathrm{H}$ & $\mathrm{H}$ & $\mathrm{H}$ & $\mathrm{H}$ & W \\
\hline $622 a$ & W & W & W & W & W & W & $\mathrm{H}$ & W & W & W \\
\hline $622 b$ & W & W & $\mathrm{H}$ & $\mathrm{ND}^{\mathrm{e}}$ & W & W & W & W & W & W \\
\hline 625 & W & W & W & W & W & W & W & W & W & W \\
\hline 627 & $\mathrm{H}$ & W & W & W & W & W & W & W & W & W \\
\hline 541 & W & W & W & W & W & $\mathrm{H}$ & W & W & W & W \\
\hline 549 & W & W & W & W & W & W & W & W & W & W \\
\hline $579 a$ & $\mathrm{~W}$ & W & W & W & W & W & W & W & W & W \\
\hline $579 b$ & $\mathrm{H}$ & W & W & W & W & W & W & W & W & W \\
\hline 587 & W & W & W & W & W & $\mathrm{H}$ & W & W & W & W \\
\hline $597 a$ & W & W & W & W & W & $\mathrm{H}$ & W & W & W & W \\
\hline 600 & $\mathrm{H}$ & $\mathrm{H}$ & $\mathrm{H}$ & $\mathrm{H}$ & W & W & W & W & W & W \\
\hline
\end{tabular}


1994). Once visible lesions began to develop on cep plants, constitutive $P R$ gene expression was activated. Interestingly, high levels of $P R$ transcripts could be detected in the healthy leaves as well as those with visible lesions (data not shown). In contrast, high levels of $P R$ expression were not found in the healthy leaves of $a c d 2$ mutant plants until at least two leaves had become completely necrotic (Greenberg et al. 1994).

Because lesion formation, $P R$ gene expression, and elevated SA levels are phenomena that correlate with disease resistance in many plant species, the response of mutant plants to infection with virulent pathogens was assessed. At every time point assayed, growth of either the M4 or M5 strain of Pseudomonas syringae pv. maculicola was lower in cep plants than in wt plants (Fig. 4). In addition, mutant plants were more resistant to infection by Peronospora parasitica isolate EMWA than wt plants. Almost none of the infected cep plants had conidiophores on their leaves, whereas all of the wt plants were efficiently colonized by Peronospora parasitica (Table 1). The reduction in pathogen growth and disease symptom severity demonstrates that cep plants exhibited enhanced disease resistance to both bacterial and fungal pathogens, presumably due to the constitutive activation of defense responses.

Based on genetic analyses of plants from the Ws ecotype, the cep phenotype is inherited as a recessive mutation at a single locus that, unfortunately, is not tagged with T-DNA. Unexpectedly, analyses of the progeny derived from crosses between Ws cep and normal plants from other ecotypes revealed that at least two unlinked mutations from the Ws cep parent play a major role in determining the cep phenotype. One mutation was mapped to the lower arm of chromosome 4, between the markers PAP7.2 and nga1107. Since this mutation is necessary for the appearance of the cep phenotype, it most likely corresponds to the mutation originally identified in the Ws ecotype. We have designated this mutation cpr20. The second mutation maps to chromosome 1 , between the $\beta$ fluctosidase gene and nga 280 . We have designated this mutation cpr21. In contrast to cpr20, cpr21 is not absolutely required for expression of the mutant phenotype, suggesting the involvement of possibly a third locus in determining the cep phenotype in the $\mathrm{F}_{2}$ segregants.

In addition to $c p r 20$, three other recessive mutations ( $l s d l$, $a c d 2$, and $c p r 1$ ), which cause constitutive $P R$ gene expression, elevated SA levels, and enhanced disease resistance, have been mapped to chromosome 4 (Dietrich et al. 1997; Greenberg et al. 1994; Bowling et al. 1997). To determine whether the mutations carried by the acd 2 and cprl mutants are allelic to cpr20, crosses between these mutants and cep plants were performed. The $\mathrm{F}_{1}$ progeny from all of these crosses neither constitutively expressed $P R$ genes nor displayed any of the cep-associated morphologies; thus, none of these mutations appear to be allelic (Table 2). The observed complementation between cpr 20 and cprl is consistent with their different patterns of $P R$ gene expression. In contrast to cep plants, whose constitutive pattern of $P R-1$, $P R-2$, and $P R-5$ expression resembles that of SA-treated wt plants, cprl only exhibits high constitutive expression of $P R-1$ and $P R-2$, with $P R-2$ transcripts accumulating to substantially higher levels than those of $P R-1$. Complementation analysis between $l s d l$ and the cep mutant was not per- formed because the $l s d l$ mutation has been shown to be tightly linked to the $A G$ locus (Dietrich et al. 1997), which our data indicate is approximately $17.6 \mathrm{cM}$ away from the CPR20 locus. Another mutant of Arabidopsis, called cpr5, which constitutively expresses $P R$ genes, contains elevated SA levels, develops spontaneous lesions, and shows enhanced resistance, has been identified (Bowling et al. 1997). Complementation analysis suggested that cpr5 and cpr20 are not allelic (Table 2). This is consistent with recent mapping studies that have placed cpr5 on chromosome 5 (Bowling et al. 1997). Several other $l s d$ mutants besides $l s d l$ have been shown to exhibit phenotypes similar to that of cep; however, complementation analyses with these mutants were not performed for several reasons. The dominant $l s d 6$ mutation maps to chromosome 1 (Weymann et al. 1995). The $l s d 2, l s d 4$, and $l s d 7$ mutants are also dominant (Dietrich et al. 1994; Weymann et al. 1995), which makes complementation analyses difficult. $l s d 3$ and $l s d 5$ have not yet been mapped, but, unlike cep, spontaneous lesion formation in these mutants is environmentally regulated (Dietrich et al. 1994), which suggests that they are not allelic to cpr20. Furthermore, while cep, $l s d 3$, and $l s d 5$ are in the same background (Ws), when crossed to Col- $0, l s d 3$ and $l s d 5$ show a pattern of inheritance consistent with a recessive mutation at a single locus (J. Dangl, personal communication).

Based on these results, the cpr20 and cpr21 mutations responsible for the cep phenotype appear to affect a novel component of a disease resistance signaling pathway upstream of SA. Moreover, the constitutive phenotype of the cep mutant suggests that the CPR20 and CPR 21 products act as early negative regulators in this defense pathway. Based on the genetic analysis of $\mathrm{F}_{2}$ segregants from a Ws cep $\times$ Col-0 wt cross, the CPR2O and CPR21 genes would appear to encode proteins with redundant functions. However, though 62 of the 79 cep segregants from the cross were $c p r 20$ cpr21 double mutants, the remaining 17 were mutant only for cpr20. These data suggest that the CPR 20 and CPR 21 products are not fully redundant and that the CPR21 product may need to be modified by the action of another gene to perform the equivalent negative function of CPR20.

Alternatively, one or more of these mutations may be in a component of another pathway that impinges on the SAmediated defense pathway at or upstream of SA. The discovery that four non-allelic mutations causing enhanced disease resistance map to a region on the lower arm of chromosome 4 is intriguing. Whether this loose clustering of resistanceassociated genes to a portion of chromosome 4 is significant from a biological or evolutionary point of view remains to be determined. The fine mapping and the cloning of the CPR2O gene located in this region on chromosome 4 and further analysis of this region should help provide a better understanding of these aspects.

\section{MATERIALS AND METHODS}

\section{Bacterial and fungal maintenance.}

Pseudomonas syringae pv. maculicola strains M4 and M5 were grown at $30^{\circ} \mathrm{C}$ in King's B medium (King et al. 1954) supplemented with rifampicin (50 $\mathrm{mg} / \mathrm{liter})$. Peronospora parasitica isolate EMWA was propagated on Ws plants as described by Dangl et al. (1992) and Dietrich et al. (1994). 


\section{Plant maintenance.}

Arabidopsis thaliana (Ws ecotype) wt and 3,000 lines of TDNA-mutagenized transgenic plants obtained from ABRC (Ohio State University) were grown in Pro-Mix (Premier Horticulture, Red Hill, PA) in a growth chamber with a 14-h light cycle $\left(140 \mu \mathrm{E} \mathrm{s}^{-1} \mathrm{~m}^{-2}\right)$ at $22^{\circ} \mathrm{C}$. Dependence of the cep phenotype on light conditions was assessed under the same conditions described by Dietrich et al. (1994). To test kanamycin resistance, seeds were surface sterilized in $0.1 \%$ Triton X-100 for $30 \mathrm{~min}, 0.1 \%$ Triton X-100 plus $70 \%$ ethanol for $5 \mathrm{~min}$, and $0.1 \%$ Triton $\mathrm{X}-100$ plus $2 \%$ commercial bleach for $10 \mathrm{~min}$, washed five times in sterile, distilled water, and sown on Murashige-Skoog (MS) media containing 0.8\% agar, $1 \%$ sucrose, and $50 \mathrm{mg}$ of kanamycin per liter. Growth conditions were the same as described above.

\section{Bacterial infections.}

One-week-old wt and cep seedlings were transferred to a growth chamber set for an 8 -h light cycle $\left(350 \mu \mathrm{E} \mathrm{s}^{-1} \mathrm{~m}^{-2}\right), 60 \%$ relative humidity $(\mathrm{RH})$, and $24 / 20^{\circ} \mathrm{C}$ (day/night). Three weeks later, four leaves per plant were infiltrated with either $10 \mathrm{mM}$ $\mathrm{MgCl}_{2}$ (mock) or suspensions of Pseudomonas syringae pv. maculicola strains M4 or M5. Bacteria were grown overnight at $30^{\circ} \mathrm{C}$ in King's B medium containing rifampicin and resuspended to $\mathrm{OD}_{600}=0.2\left(10^{8} \mathrm{CFU} \mathrm{ml}^{-1}\right)$ in $10 \mathrm{mM} \mathrm{MgCl}_{2}$. Plants were infected with the M4 strain at a dose of $10^{5} \mathrm{CFU} \mathrm{ml}^{-1}$; the M5 strain was used at $10^{4} \mathrm{CFU} \mathrm{ml^{-1 }}$. Infiltration and analysis of bacterial growth were performed as described by Shah et al. (1997), except that rifampicin (50 mg/ liter) was the only antibiotic used. Three independent experiments were done.

\section{Fungal infections.}

cep and wt seeds were sown on soil and placed in a growth chamber with a 10 -h light cycle $\left(150 \mu \mathrm{E} \mathrm{s}^{-1} \mathrm{~m}^{-2}\right)$ at $18^{\circ} \mathrm{C}$ and $90 \% \mathrm{RH}$. At the time of the infection, growth conditions were changed to $17^{\circ} \mathrm{C}, 10$-h light cycle $\left(75 \mu \mathrm{E} \mathrm{s}^{-1} \mathrm{~m}^{-2}\right)$, and $99 \%$ RH (accomplished by placing the plants inside plastic bags). Infection and analysis of Peronospora parasitica isolate EMWA growth were performed as described in Dangl et al. (1992) and Dietrich et al. (1994) except that 5-week-old plants were used. This experiment was done twice.

\section{Free SA and SAG analyses.}

Determination of free SA and SAG levels in wt and cep plants was performed with $0.5 \mathrm{~g}$ fresh weight of leaf tissue as described by Bowling et al. (1994). The data shown have been adjusted for the approximately $50 \%$ recovery of SA during extraction.

\section{RNA and DNA analyses.}

Total RNA was extracted from leaves of pooled or individual plants with the reagent TRIzol (Gibco-BRL, Gaithersburg, MD) according to the manufacturer's instructions. Genomic DNA was extracted according to Das et al. (1990).

Southern analyses were performed according to Shah et al. (1997), except $5 \mu \mathrm{g}$ of total genomic DNA was used. Northern analyses were performed as described by Conrath et al. (1997). Probes specific for the Arabidopsis $P R-1, B G L 2$, ( $P R-$ 2 ), and $P R-5$ genes, and the right and left borders of the TDNA insert, were generated by random-primer labeling the inserts of various cDNA clones.

\section{Mutant isolation.}

A titration was initially performed to determine the sensitivity of our screen for mutants with constitutive expression of the $P R-1$ gene. RNA extracted from plants treated (subirrigation) with $500 \mu \mathrm{M}$ SA for $24 \mathrm{~h}$ was diluted with differing amounts of RNA extracted from untreated plants. With $20 \mu \mathrm{g}$ of a 1:20 dilution, $P R-1$ mRNA was still readily detected on a Northern blot after the autoradiogram was exposed overnight.

Sixty seeds representing 20 lines were sown in pools of 20 seeds each. From 3 -week-old plants, single leaves from each plant in the pool were detached, combined, and used for total RNA extraction. Twenty micrograms of RNA from each pool, along with $20 \mu \mathrm{g}$ of a positive control (consisting of a 1:20 dilution of RNA from SA-treated versus untreated plants) was subjected to Northern blot analysis. Any pool containing elevated levels of $P R-1$ mRNA was then analyzed in greater detail by extracting RNA from the individual plants within the pool and subjecting $10 \mu \mathrm{g}$ of each to Northern blot analysis to identify the putative mutant plant. One line exhibiting constitutive expression of $P R-1$ (cep) was isolated from 3,000 TDNA-mutagenized lines (Feldmann 1992). This putative mutant was allowed to self-pollinate and the cep phenotype was confirmed in the next generation.

\section{Genetic analysis of cep.}

For all crosses, cep plants derived from the ecotype Ws were used as the pollen-accepting plants. To determine the basis of the cep phenotype, cep homozygous plants were crossed to wt Ws plants. The $\mathrm{F}_{1}$ progeny were scored for $\mathrm{Kan}^{\mathrm{r}}$ and constitutive expression of $P R-1$ at 3 weeks. To determine the chromosomal location of the mutation responsible for the cep phenotype, cep plants were crossed to Columbia ecotype (Col-0). The $\mathrm{F}_{1}$ progeny were allowed to self-pollinate and the $\mathrm{F}_{2}$ progeny were scored for the curly leaf morphology and necrotic cotyledons associated with the cep phenotype. Analysis of $P R-1$ expression was performed on $\mathrm{F}_{3}$ progeny to confirm the cep phenotype. These cep plants were used for CAPS and SSLP marker analysis (Bell and Ecker 1994; Konieczny and Ausubel 1993). DNA was isolated from individual plants as described by Edwards et al. (1991) and the polymerase chain reactions (PCRs) for CAPS markers were performed as described by Konieczny and Ausubel (1993) except that $0.04 \mu \mathrm{g}$ of primers was used instead of $0.2 \mu \mathrm{g}$ and the PCR products were separated in a $2 \%$ agarose gel. SSLP markers were used to fine map mutations on chromosome 4 and chromosome 1 . PCR conditions for SSLP markers were as described by Bell and Ecker (1994) except that $\mathrm{KCl}$, Tris- $\mathrm{HCl}$, gelatin, and Triton X-100 were excluded from the reactions and the PCR products were fractionated in a $4 \%$ agarose gel.

All primers were purchased from Research Genetics (Huntsville, AL). Linkage analysis and genetic map distances were calculated with the MapMaker Macintosh V2.0 program with a maximum theta equal to 0.40 and a minimum LOD score of 3.00 (Landers et al. 1987). The Kosambi map function (Kosambi 1944) was used to convert the recombination frequencies to map distances in centimorgans (Koornneef and Stam 1992). Crosses between cep and the different mutants were analyzed for curly leaf morphology and necrotic cotyledons as well as constitutive expression of the $P R-1$ gene. These analyses were performed on 3-week-old plants. 


\section{Microscopic analysis of cell-wall-associated autofluorescent materials.}

cep and wt cotyledons were analyzed at 6, 8, 10, and 14 $\mathrm{dpp}$, while leaves were monitored for lesion formation from 1 to 5 weeks. Cotyledons and leaves were analyzed as described by Dempsey et al. (1997).

\section{ACKNOWLEDGMENTS}

We thank the Arabidopsis Biological Resource Center at Ohio State University for the Agrobacterium tumefaciens-transformed lines (CS 3116 and CS 6400) and ecotypes Ws and Columbia, Col-0. We also acknowledge Jeff Dangl for providing us with the Pseudomonas syringae strains, Xinnian Dong for providing seeds for the cpr1 and cpr5 mutants, NahG transgenic Arabidopsis, and Peronospora parasitica isolate EMWA, Fred Ausubel for providing seeds for the acd 2 mutants, and Frank Tsui and Maria Corado for technical assistance in the screening. We gratefully acknowledge D'Maris Dempsey for assistance in preparing this manuscript and Lee Meisel, Jyoti Shah, and Roy Navarre for their suggestions and critical reading of this manuscript. This work was supported by grants MCB 9310371 and MCB 9723952 from the National Science Foundation to D. F. K.

\section{LITERATURE CITED}

Bell, C. J., and Ecker, J. R. 1994. Assignment of 30 microsatellite loci to the linkage map of Arabidopsis. Genomics 19:137-144.

Bowles, D. J. 1990. Defense-related proteins in higher plants. Annu. Rev. Biochem. 59:873-907.

Bowling, S. A., Clarke, J. D., Liu, Y., Klessig, D. F., and Dong, X. 1997. The cpr 5 mutant of Arabidopsis expresses both NPR1-dependent and NPR1-independent resistance. Plant Cell 9:1573-1584.

Bowling, S. A., Guo, A., Cao, H., Gordon, A. S., Klessig, D. F., and Dong, X. 1994. A mutation in Arabidopsis that leads to constitutive expression of systemic acquired resistance. Plant Cell 6:1845-1857.

Bradley, D. J., Kjellbom, P., and Lamb, C. J. 1992. Elicitor- and woundinduced oxidative cross-linking of a proline-rich plant cell wall protein: A novel, rapid defense response. Cell 70:21-30.

Brisson, L. F., Tenhaken, R., and Lamb, C. J. 1994. Function of oxidative cross-linking of cell wall structural proteins in plant disease resistance. Plant Cell 6:1703-1712.

Chester, K. S. 1933. The problem of acquired physiological immunity in plants. Q. Rev. Biol. 8:275-324.

Conrath, U., Silva, H., and Klessig, D. F. 1997. Protein dephosphorylation mediates salicylic acid-induced expression of $P R-1$ genes in tobacco. Plant J. 11:747-757.

Dangl, J. L., Holub, E. B., Debener, T., Lehnackers, H., Ritter, C., and Crute, I. R. 1992. Genetic definition of loci involved in Arabidopsispathogen interactions. Pages 393-418 in: Methods in Arabidopsis Research. C. Koncz, N. Chua, and J. Schell, eds. World Scientific, Singapore.

Das, O. P., Alvarez, C., Chaudhuri, S., and Messing, J. 1990. Molecular methods for genetic analysis of maize. Methods Mol. Cell. Biol. 1: 213-222.

Delaney, T. P., Uknes, S., Vernooij, B., Friedrich, L., Weymann, K., Negrotto, D., Gaffney, T., Gut-Rella, M., Kessmann, H., Ward, E., and Ryals, J. 1994. A central role of salicylic acid in plant disease resistance. Science 266:1247-1250.

Dempsey, D. A., Pathirana, M. S., Wobbe, K. W., and Klessig, D. F. 1997. Identification of an Arabidopsis locus required for resistance to turnip crinkle virus. Plant J. 11:301-311.

Dietrich, R. A., Delaney, T. P., Uknes, S. J., Ward, E. R., Ryals, J. A., and Dangl, J. L. 1994. Arabidopsis mutants simulating disease resistance response. Cell 77:565-577.

Dietrich, R. A., Richberg, M. H., Schmidt, R., Dean, C., and Dangl, J. L. 1997. A novel zinc finger protein is encoded by the Arabidopsis LSD1 gene and functions as a negative regulator of plant cell death. Cell 88: 685-694.

Dixon, R. A. 1986. The phytoalexin response: elicitation, signaling, and control of host gene expression. Biol. Rev. Camb. Philos. Soc. 61: 239-292.
Durner, J., Shah, J., and Klessig, D. F. 1997. Salicylic acid and disease resistance in plants. Trends Plant Sci. 19:266-274.

Edwards, K., Johnstone, C., and Thompson, C. 1991. A rapid and simple method for the preparation of plant genomic DNA for PCR analysis. Nucleic Acid Res. 19:1349.

Enyedi, A. J., Yalpani, N., Silverman, P., and Raskin, I. 1992. Localization, conjugation, and function of salicylic acid in tobacco during the hypersensitive reaction to tobacco mosaic virus. Proc. Natl. Acad. Sci. USA 89:2480-2484.

Feldmann, K. A. 1992. T-DNA insertion mutagenesis in Arabidopsis: seed infection/transformation. Pages 274-289 in: Methods in Arabidopsis Research. C. Koncz, N. Chua, and J. Schell, eds. World Scientific, Singapore.

Frye, C. A., and Innes, R. W. 1998. An Arabidopsis mutant with enhanced resistance to powdery mildew. Plant Cell 10:947-956.

Gaffney, T., Friedrich, L., Vernooij, B., Negrotto, D., Nye, G., Uknes, S., Ward, E., Kessmann, H., and Ryals, J. 1993. Requirement of salicylic acid for the induction of systemic acquired resistance. Science 261: 754-756.

Greenberg, J. T., Guo, A., Klessig, D. F., and Ausubel, F. M. 1994. Programmed cell death in plants: A pathogen triggered response activated coordinately with multiple defense functions. Cell 77:551-563.

Keen, N. T. 1990. Gene-for-gene complementation in plant-pathogen interaction. Annu. Rev. Genet. 24:447-463.

King, E. O., Ward, M. K., and Raney, D. E. 1954. Two simple media for the demonstration of phycocyanin and fluorescein. J. Lab. Clin. Med. 44:301-307.

Kombrink, E., and Sommssich, I. E. 1997. Pathogenesis-related proteins and plant defense. Pages 107-128 in Plant Relationships: The Mycota. Vol. 5. Part A. G. Carrol and P. Tudzynski, eds. Berlin, SpringerVerlag.

Konieczny, A., and Ausubel, F. M. 1993. A procedure for mapping Arabidopsis mutations using co-dominant ecotype-specific PCRbased markers. Plant J. 4:403-410.

Koornneef, M., and Stam, P. 1992. Genetic analysis. Pages 83-89 in: Methods in Arabidopsis Research. C. Koncz, N. Chua, and J. Schell, eds. World Scientific, Singapore.

Kosambi, D. D. 1944. The estimation of map distances from recombination values. Ann. Eugen. 12:172-175.

Landers, E. S., Green, P., Abrahamson, J., Barlow, A., Daly, M. J., Lincoln, S. E., and Newberg, L. 1987. Mapmaker: An interactive computer package for constructing primary genetic linkage maps of experimental and natural populations. Genetics 121:174-181.

Lummerzheim, M., de Oliveira, D., Castresana, C., Miguens, F. C., Louzada, E., Roby, D., Van Montagu, M., and Timmerman, B. 1993. Identification of compatible and incompatible interactions between Arabidopsis thaliana and Xanthomonas campestris pv. campestris and characterization of the hypersensitive response. Mol. Plant-Microbe Interact. 6:532-544.

Malamy, J., Carr, J. P., Klessig, D. F., and Raskin, I. 1990. Salicylic acid: A likely endogenous signal in the resistance response of tobacco to viral infection. Science 250:1002-1004.

Malamy, J., Hennig, J., and Klessig, D. F. 1992. Temperature-dependent induction of salicylic acid and its conjugates during the resistance response to tobacco mosaic virus infection. Plant Cell 4:359-366.

Matthews, R. E. F. 1991. Plant Virology. 3rd ed. Academic, San Diego, CA.

Métraux, J.-P., Signer, H., Ryals, J., Ward, E., Wyss-Benz, M., Gaudin, J., Raschdorf, K., Schmid, E., Blum, W., and Inverardi, B. 1990. Increase in salicylic acid at the onset of systemic acquired resistance in cucumber. Science 250:1004-1006.

Mauch-Mani, B., and Slusarenko, A. J. 1996. Production of salicylic acid precursors is a major function of phenyalanine ammonia-lyase in the resistance of Arabidopsis to Peronospora parasitica. Plant Cell 8: 203-212.

Ross, A. F. 1961. Systemic acquired resistance induced by localized virus infection in plants. Virology 14:340-358.

Ryals, J. A., Neuenschwander, U. H., Willits, M. G., Molina, A., Steiner, H.-Y. and Hunt, M. D. 1996. Systemic acquired resistance. Plant Cell 8:1809-1819.

Schröder, M., Hahlbrock, K., and Kombrink, E. 1992. Temporal and spatial patterns of 1,3- $\beta$-glucanase and chitinase induction in potato leaves infected by Phytophthora infestans. Plant J. 2:161-172.

Scofield, S. R., Tobias, C. M., Rathjen, J. P., Chang, J. H., Lavelle, D. T., 
Michelmore, R. W., and Staskawicz, B. J. 1996. Molecular basis of gene-for-gene specificity in bacterial speck disease of tomato. Science 274:2063-2065.

Shah, J., Kachroo, P., and Klessig, D. F. 1999. The Arabidopsis ssil mutation restores pathogenesis-related gene expression in nprl plants and renders defensin gene expression SA dependent. Plant Cell 11: 191-206.

Shah, J., Tsui, F., and Klessig, D. F. 1997. Characterization of a salicylic acid-insensitive mutant (sail) of Arabidopsis thaliana, identified in a selective screen utilizing the SA-inducible expression of the tms 2 gene. Mol. Plant-Microbe Interact. 10:69-78.

Slusarenko, A. J., Croft, K. P., and Voisey, C. R. 1991. Biochemical and molecular events in the hypersensitive response of bean to Pseudomonas syringae pv. phaseolicola. Pages 126-143 in: Biochemistry and Molecular Biology of Plant-Pathogen Interactions. C. J. Smith, ed. Oxford University Press, Oxford.

Tang, X., Frederick, R. D., Zhou, J., Halterman, D. A., Jia, Y., and Martin, G. B. 1996. Initiation of plant disease resistance by physical interaction of AvrPto and the Pto kinase. Science 274:2060-2063.

Uknes, S., Winter, A. M., Delaney, T., Vernooij, B., Morse, A., Friedrich, L., Nye, G., Potter, S., Ward, E., and Ryals, J. 1993. Biological induction of systemic acquired resistance in Arabidopsis. Mol. PlantMicrobe Interact. 6:692-698.

Ward, E. R., Uknes, S. J., Williams, S. C., Dincher, S. S., Wiederhold, D. L., Alexander, D. C., Ahl-Goy, P., Métraux, J.-P., and Ryals, J. A. 1991. Coordinate gene activity in response to agents that induce systemic acquired resistance. Plant Cell 3:1085-1094.

Weymann, K., Hunt, M., Uknes, S., Neuenschwander, U., Lawton, K., Steiner, H.-Y., and Ryals, J. 1995. Suppression and restoration of lesion formation in Arabidopsis lsd mutants. Plant Cell 7:20132022.

White, R. F. 1979. Acetylsalicylic acid (aspirin) induces resistance to tobacco mosaic virus in tobacco. Virology 99:410-412.

Yang, Y., Shah, J., and Klessig, D. F. 1997. Signal perception and transduction in plant defense responses. Genes Dev. 11:1621-1639.

Yu, G.-L, Katagiri, F., and Ausubel, F. M. 1993. Arabidopsis mutations at the RPS2 locus result in loss of resistance to Pseudomonas syringae strains expressing the avirulence gene avrRpt2. Mol. Plant-Microbe Interact. 6:434-443.

Yu, I.-C., Parker, J., and Bent, A. F. 1998. Gene-for-gene disease resistance without the hypersensitive response in Arabidopsis dndl mutant. Proc. Natl. Acad. Sci. USA 95:7819-7824. 